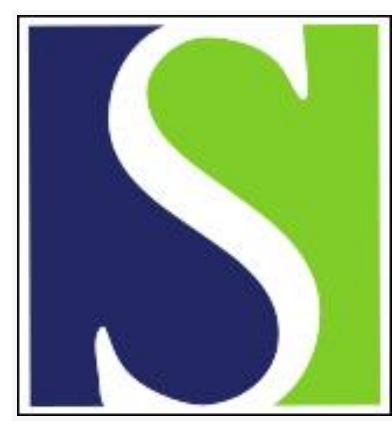

Scand J Work Environ Health 1992;18(1):59-63

https://doi.org/10.5271/sjweh.1608

Issue date: 28 Feb 1992

\title{
Osteoarthritis of the hip and occupational activity.
}

by Croft P, Cooper C, Wickham C, Coggon D

Affiliation: Medical Research Council, University of Southampton, Southampton General Hospital, United Kingdom.

The following article refers to this text: 2013;39(5):486-494

This article in PubMed: www.ncbi.nlm.nih.gov/pubmed/1553513

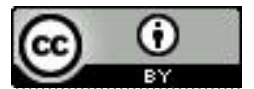




\title{
Osteoarthritis of the hip and occupational activity
}

\author{
by Peter Croft, MRCGP, ${ }^{1}$ Cyrus Cooper, MRCP, ${ }^{2}$ Carol Wickham, MSc, ${ }^{1}$ David Coggon MRCP ${ }^{1}$
}

\begin{abstract}
CROFT P, COOPER C, WICKHAM C, COGGON D. Osteoarthritis of the hip and occupational activity. Scand $J$ Work Environ Health 1992;18:59-63. This case-referent study investigated the relation between hip osteoarthritis and occupational activity. The subjects were 60 - to 75 -year-old men who had undergone intravenous urography. Interviews were obtained for 245 cases who had a hip replacement for osteoarthritis or a joint space of $\leq 2.5 \mathrm{~mm}$ and 294 referents whose joint space was $\geq 3.5 \mathrm{~mm}$ in both hips. No clear associations were found in an analysis of all the cases, but severe disease (hip replacement for osteoarthritis or a joint space of $\leq 1.5 \mathrm{~mm}$ ) was more common in the farmers, especially in those with $\geq 10$ years in agricultural work [odds ratio (OR) $2.0,95 \%$ confidence interval $(95 \% \mathrm{CI}) 0.9-4.4$ ]. Severe disease was also associated with prolonged standing at work (OR 2.7, 95\% CI 1.0-7.3) and heavy lifting (OR $2.5,95 \%$ CI 1.1-5.7). These associations could not be explained by obesity or sporting activity. The findings suggest an increased risk of degenerative hip disease for farmers and indicate that mechanical overloading may contribute to its pathogenesis.
\end{abstract}

Key terms: hip, occupational diseases, osteoarthritis, risk factors, sports.

The repetitive use and excessive mechanical loading of certain joints appear to cause osteoarthritis. Thus, for example, cotton mill workers are unusually prone to degenerative change in the joints of their fingers (1), and osteoarthritis of the knee is associated with weight bearing and bending of the knee at work (2). The contribution of mechanical stress to osteoarthritis of the hip is, however, less certain. A survey of patients with asymmetrical paralysis of the lower limbs following poliomyelitis showed a lower prevalence of hip osteoarthritis on the weaker side (3). But examinations of runners and ballplayers who stress their hips in the course of their sport have produced conflicting findings, some studies indicating high rates of osteoarthritis (4-5) and others no such increased risk (6-9).

Occupation is an important determinant of cumulative stress on the hip joint, but few studies have examined the relation of hip osteoarthritis to occupation. Cross-sectional surveys of industrial populations have suggested that risk differs little for manual and nonmanual workers $(10,11)$. However, people with severe disease may have been selected out from the most physically demanding jobs, and the findings cannot therefore be regarded as conclusive. When occupations have been classified more specifically, the most consistent observation has been an increased prevalence among agricultural workers $(12-16)$. If real, this association could provide clues to the pathogenesis of

\footnotetext{
${ }^{1}$ Medical Research Council, Environmental Epidemiology Unit, University of Southampton, Southampton General Hospital, Southampton, United Kingdom.

2 Rheumatology Unit, Department of Medicine, Bristol Royal Infirmary, Bristol, United Kingdom.
}

Reprint requests to: Dr P Croft, ARC Epidemiology Research Unit, Stopford Building (University of Manchester), Oxford Road, Manchester M13 9PT, United Kingdom. the disease. We have therefore carried out a casereferent study of osteoarthritis of the hip and occupation, looking particularly at risk in relation to farming and at occupational activities which might explain an association with agricultural work.

\section{Subjects and methods}

The cases and referents were ascertained through the radiology departments of the North Staffordshire and Shrewsbury hospitals. From X-ray registers we identified all men who had had an outpatient intravenous urogram during 1982-1987 and who were aged 60-75 years at the time of the examination. Most of these examinations were performed for prostatic symptoms. We then assessed their hip joints from the reference or postmicturition film. A radiograph was excluded if neither hip could be adequately visualized. If a patient had been examined more than once during the study period, the earliest suitable radiograph was used.

We took as cases those men who had had a total hip replacement for osteoarthritis and those in whom the shortest distance between the femoral head and the acetabular roof (the "minimal joint space") was less than or equal to $2.5 \mathrm{~mm}$ in at least one hip. Within this group we defined a subset of "severe" cases with a hip replacement or a minimal joint space of less than or equal to $1.5 \mathrm{~mm}$ in at least one hip. Our reference group comprised those men whose minimal joint space was greater than or equal to $3.5 \mathrm{~mm}$ in both hips and who showed no other radiographic evidence of osteoarthritis (ie, no osteophytes, no cysts, and no subchondral sclerosis of more than $5 \mathrm{~mm}$ in thickness).

The cases and referents were approached through their general practitioners to exclude those who had died since their radiographic examination and those 
who were too ill to be seen. The men who agreed to participate were interviewed in their homes by a single interviewer (PC), who was unaware of their status as a case or a referent. The information sought included a lifetime occupational history with details of whether or not jobs involved each of 12 specified activities, and a history of sports and hobbies pursued since leaving school. Heights were measured with a Harpenden stadiometer, and weights with portable scales (Seca).

The subjects' occupations were coded according to the 1970 classification of the Office of Population Censuses and Surveys (17), and the subjects were grouped according to how long they had worked in each of eight occupational categories before the radiographic exami-

Table 1. Numbers of cases and referents interviewed and reasons for incomplete response.

\begin{tabular}{lrc}
\hline & Cases & Referents \\
\cline { 2 - 3 } Subject untraceable & 17 & 22 \\
Subject dead or too ill for interview & 38 & 57 \\
Subject declined interview & 36 & 44 \\
No interview for other reasons & 7 & 10 \\
Interview unsatisfactory (eg, because & & \\
subject was confused) & 10 & 7 \\
Interview satisfactorily completed & 245 & 294 \\
\hline
\end{tabular}

nation. These categories were selected to cover the most commonly reported jobs in the study sample and were defined before any comparisons were made between the cases and referents. In the analysis of occupational activities, the subjects were classified according to how long they had been exposed to each activity. The durations of exposure were grouped into two or three levels, which again were defined before any casereferent comparisons.

The odds ratios (OR) for associations with osteoarthritis were estimated by logistic regression with adjustment for age at the time of the radiographic examination (60-64, 65-69, and 70-75 years) and hospital group (North Staffordshire, Shrewsbury).

\section{Results}

From the radiographs we identified 353 cases and 434 referents, of whom 245 cases $(69 \%)$ and 294 referents $(68 \%)$ were interviewed. The reasons for the incomplete response are summarized in table 1 . One hundred and fifty-three interviewed cases were from North Staffordshire and 92 were from Shrewsbury. They included 53 severe cases, of whom seven had had hip replacements for osteoarthritis.

Table 2 shows the relation between osteoarthritis of the hip and the most frequently reported occupations

Table 2. Associations between osteoarthritis of the hip and selected occupations. ${ }^{\text {a }}$ (OR $=$ odds ratio, $95 \% \mathrm{Cl}=95 \%$ confidence interval)

\begin{tabular}{|c|c|c|c|c|c|c|c|}
\hline \multirow{2}{*}{ Occupation ${ }^{b}$} & \multirow{2}{*}{$\begin{array}{l}\text { Referents } \\
\text { (N) }\end{array}$} & \multicolumn{3}{|c|}{ All cases } & \multicolumn{3}{|c|}{ Severe cases } \\
\hline & & N & OR & $95 \% \mathrm{Cl}$ & $\mathrm{N}$ & OR & $95 \% \mathrm{Cl}$ \\
\hline Farmers and agricultural workers $(002,003)$ & 65 & 52 & 0.9 & $0.6-1.4$ & 19 & 1.6 & $0.8-3.1$ \\
\hline Underground coal miners $(007)$ & 33 & 22 & 0.8 & $0.4-1.4$ & 3 & 0.6 & $0.2-2.3$ \\
\hline Ceramics makers and laborers $(013-017,112)$ & 49 & 42 & 1.0 & $0.6-1.6$ & 8 & 1.2 & $0.5-3.0$ \\
\hline Construction workers and laborers $(093-098,113)$ & 37 & 35 & 1.2 & $0.7-1.9$ & 9 & 1.5 & $0.7-3.4$ \\
\hline Truck, bus and car drivers $(120-122)$ & 51 & 41 & 0.9 & $0.6-1.4$ & 11 & 1.1 & $0.5-2.4$ \\
\hline Warehousemen (136) & 27 & 26 & 1.1 & $0.6-1.9$ & 6 & 1.3 & $0.5-3.5$ \\
\hline Clerks (139) & 49 & 38 & 0.9 & $0.6-1.5$ & 9 & 1.1 & $0.5-2.4$ \\
\hline Shop workers (143-144) & 31 & 28 & 1.2 & $0.7-2.1$ & 3 & 0.6 & $0.2-2.1$ \\
\hline
\end{tabular}

a Odds ratios were estimated for each occupation independently, with adjustment for age and hospital group. They are for men who worked in the occupation for at least one year relative to those who did not.

b Code of the Classification of Occupations of the Office of Population Censuses and Surveys (17) in parentheses.

Table 3. Associations between osteoarthritis of the hip and lifetime duration of employment in farming and construction work. ${ }^{a}$ (OR $=$ odds ratio, $95 \% \mathrm{Cl}=95 \%$ confidence interval)

\begin{tabular}{|c|c|c|c|c|c|c|c|}
\hline \multirow{2}{*}{ Occupation } & \multirow{2}{*}{$\begin{array}{l}\text { Referents } \\
\text { (N) }\end{array}$} & \multicolumn{3}{|c|}{ All cases } & \multicolumn{3}{|c|}{ Severe cases } \\
\hline & & $\mathrm{N}$ & OR & $95 \% \mathrm{Cl}$ & $\mathrm{N}$ & OR & $95 \% \mathrm{Cl}$ \\
\hline \multicolumn{8}{|c|}{ Farmers and agricultural workers } \\
\hline $\begin{array}{l}<1 \text { year of employment } \\
1-9 \text { years of employment } \\
\geq 10 \text { years of employment }\end{array}$ & $\begin{array}{r}229 \\
28 \\
37\end{array}$ & $\begin{array}{r}193 \\
19 \\
33\end{array}$ & $\begin{array}{l}1 \\
0.8 \\
1.0\end{array}$ & $\begin{array}{l}0.4-1.5 \\
0.6-1.8\end{array}$ & $\begin{array}{r}34 \\
4 \\
15\end{array}$ & $\begin{array}{l}1 \\
1.0 \\
2.0\end{array}$ & $\begin{array}{l}0.3-3.1 \\
0.9-4.4\end{array}$ \\
\hline \multicolumn{8}{|c|}{ Construction workers and laborers } \\
\hline $\begin{array}{l}<1 \text { year of employment } \\
1-9 \text { years of employment } \\
\geq 10 \text { years of employment }\end{array}$ & $\begin{array}{r}257 \\
13 \\
24\end{array}$ & $\begin{array}{r}210 \\
20 \\
15\end{array}$ & $\begin{array}{l}1 \\
1.9 \\
0.8\end{array}$ & $\begin{array}{l}0.9-4.0 \\
0.4-1.5\end{array}$ & $\begin{array}{r}44 \\
7 \\
2\end{array}$ & $\begin{array}{l}1 \\
3.3 \\
0.5\end{array}$ & $\begin{array}{l}1.2-9.2 \\
0.1-2.3\end{array}$ \\
\hline
\end{tabular}

a Odds ratios were estimated for each occupation independently, with adjustment for age and hospital group. 
in the study sample. A comparison of all the cases with all the referents did not point to any occupational associations, but, when the analysis was restricted to severe cases, the odds ratio was moderately elevated for those who had worked for at least one year as a farmer or agricultural worker (OR 1.6) or as a construction worker or laborer (OR 1.5). To explore these associations further, we calculated the odds ratios according to the length of employment in each job (table 3). There was no evidence of à dose-response effect in relation to construction work, but among the farmers and agricultural workers the risk of severe disease was highest for those who had been in the job for more than 10 years (OR $2.0,95 \%$ CI $0.9-4.4$ ).

Table 4 illustrates the relation between osteoarthritis of the hip and the duration of exposure to occupational activities. The analysis using all of the cases showed significant associations with work that entailed standing for more than $2 \mathrm{~h} / \mathrm{d}$, but otherwise was unremarkable. When attention was restricted to severe cases, a more interesting pattern emerged. Again risk was increased for the men whose jobs had required

Table 4. Associations between osteoarthritis of the hip and lifetime duration of exposure to occupational activities. ${ }^{a}(O R=$ odds ratio, $95 \% \mathrm{Cl}=95 \%$ confidence interval)

\begin{tabular}{|c|c|c|c|c|c|c|c|}
\hline \multirow{2}{*}{ Occupational activity } & \multirow{2}{*}{$\begin{array}{l}\text { Referents } \\
\text { (N) }\end{array}$} & \multicolumn{3}{|c|}{ All cases } & \multicolumn{3}{|c|}{ Severe cases } \\
\hline & & $\mathrm{N}$ & OR & $95 \% \mathrm{Cl}$ & $\mathrm{N}$ & OR & $95 \% \mathrm{Cl}$ \\
\hline \multicolumn{8}{|l|}{ Sitting for $>2 \mathrm{~h} / \mathrm{d}$} \\
\hline $\begin{array}{l}<1 \text { year of exposure } \\
1-19 \text { years of exposure } \\
\geq 20 \text { years of exposure }\end{array}$ & $\begin{array}{r}78 \\
91 \\
114\end{array}$ & $\begin{array}{r}59 \\
67 \\
103\end{array}$ & $\begin{array}{l}1 \\
1.1 \\
1.2\end{array}$ & $\begin{array}{l}0.7-1.7 \\
0.8-1.8\end{array}$ & $\begin{array}{l}14 \\
16 \\
18\end{array}$ & $\begin{array}{l}1 \\
1.0 \\
0.8\end{array}$ & $\begin{array}{l}0.4-2.2 \\
0.3-1.7\end{array}$ \\
\hline \multicolumn{8}{|l|}{ Standing for $>2 \mathrm{~h} / \mathrm{d}$} \\
\hline $\begin{array}{l}<20 \text { years of exposure } \\
20-39 \text { years of exposure } \\
\geq 40 \text { years of exposure }\end{array}$ & $\begin{array}{r}59 \\
78 \\
147\end{array}$ & $\begin{array}{r}34 \\
67 \\
131\end{array}$ & $\begin{array}{l}1 \\
1.8 \\
1.7\end{array}$ & $\begin{array}{l}1.0-3.1 \\
1.0-2.8\end{array}$ & $\begin{array}{r}5 \\
10 \\
36\end{array}$ & $\begin{array}{l}1 \\
1.5 \\
2.7\end{array}$ & $\begin{array}{l}0.5-4.8 \\
1.0-7.3\end{array}$ \\
\hline \multicolumn{8}{|l|}{ Bending for $>2 \mathrm{~h} / \mathrm{d}$} \\
\hline $\begin{array}{l}<1 \text { year of exposure } \\
1-19 \text { years of exposure } \\
\geq 20 \text { years of exposure }\end{array}$ & $\begin{array}{r}58 \\
101 \\
100\end{array}$ & $\begin{array}{l}55 \\
58 \\
99\end{array}$ & $\begin{array}{l}1 \\
0.7 \\
1.2\end{array}$ & $\begin{array}{l}0.4-1.1 \\
0.7-1.9\end{array}$ & $\begin{array}{r}9 \\
10 \\
27\end{array}$ & $\begin{array}{l}1 \\
0.8 \\
1.9\end{array}$ & $\begin{array}{l}0.3-2.0 \\
0.8-4.5\end{array}$ \\
\hline \multicolumn{8}{|l|}{ Kneeling for $>30 \mathrm{~min} / \mathrm{d}$} \\
\hline $\begin{array}{l}<1 \text { year of exposure } \\
1-19 \text { years of exposure } \\
\geq 20 \text { years of exposure }\end{array}$ & $\begin{array}{r}170 \\
48 \\
26\end{array}$ & $\begin{array}{r}154 \\
26 \\
17\end{array}$ & $\begin{array}{l}1 \\
0.6 \\
0.7\end{array}$ & $\begin{array}{l}0.4-1.0 \\
0.4-1.3\end{array}$ & $\begin{array}{r}33 \\
4 \\
4\end{array}$ & $\begin{array}{l}1 \\
0.5 \\
1.0\end{array}$ & $\begin{array}{l}0.2-1.4 \\
0.3-3.2\end{array}$ \\
\hline \multicolumn{8}{|l|}{ Squatting for $>30 \mathrm{~min} / \mathrm{d}$} \\
\hline $\begin{array}{l}<1 \text { year of exposure } \\
\geq 1 \text { year of exposure }\end{array}$ & $\begin{array}{r}208 \\
30\end{array}$ & $\begin{array}{r}174 \\
16\end{array}$ & $\begin{array}{l}1 \\
0.7\end{array}$ & $0.4-1.4$ & $\begin{array}{r}35 \\
5\end{array}$ & $\begin{array}{l}1 \\
1.3\end{array}$ & $0.4-3.6$ \\
\hline \multicolumn{8}{|l|}{ Walking $>2$ miles $/ \mathrm{d}(3.2 \mathrm{~km} / \mathrm{d})$} \\
\hline $\begin{array}{l}<1 \text { year of exposure } \\
1-19 \text { years of exposure } \\
\geq 20 \text { years of exposure }\end{array}$ & $\begin{array}{r}32 \\
97 \\
146\end{array}$ & $\begin{array}{r}32 \\
80 \\
117\end{array}$ & $\begin{array}{l}1 \\
0.8 \\
0.8\end{array}$ & $\begin{array}{c}\cdot \\
0.5-1.5 \\
0.5-1.5\end{array}$ & $\begin{array}{r}4 \\
16 \\
31\end{array}$ & $\begin{array}{l}1 \\
1.4 \\
1.6\end{array}$ & $\begin{array}{l}0.4-4.6 \\
0.5-5.1\end{array}$ \\
\hline \multicolumn{8}{|c|}{$\begin{array}{l}\text { Walking }>2 \text { miles } / \mathrm{d}(3.2 \mathrm{~km} / \mathrm{d}) \text { over } \\
\text { rough ground }\end{array}$} \\
\hline $\begin{array}{l}<1 \text { year of exposure } \\
1-19 \text { years of exposure } \\
\geq 20 \text { years of exposure }\end{array}$ & $\begin{array}{r}146 \\
63 \\
55\end{array}$ & $\begin{array}{r}115 \\
60 \\
43\end{array}$ & $\begin{array}{l}1 \\
1.2 \\
1.0\end{array}$ & $\begin{array}{l}0.7-1.8 \\
0.6-1.6\end{array}$ & $\begin{array}{l}18 \\
17 \\
14\end{array}$ & $\begin{array}{l}1 \\
2.0 \\
1.9\end{array}$ & $\begin{array}{l}0.9-4.3 \\
0.9-4.1\end{array}$ \\
\hline \multicolumn{8}{|l|}{ Running for $>1 \mathrm{~h} / \mathrm{d}$} \\
\hline $\begin{array}{l}<1 \text { year of exposure } \\
\geq 1 \text { year of exposure }\end{array}$ & $\begin{array}{r}259 \\
10\end{array}$ & $\begin{array}{r}218 \\
10\end{array}$ & $\begin{array}{l}1 \\
1.3\end{array}$ & $0.5-3.3$ & $\begin{array}{r}49 \\
1\end{array}$ & $\begin{array}{l}1 \\
0.5\end{array}$ & $0.1-4.2$ \\
\hline \multicolumn{8}{|l|}{ Climbing ladders } \\
\hline $\begin{array}{l}<1 \text { year of exposure } \\
1-19 \text { years of exposure } \\
\geq 20 \text { years of exposure }\end{array}$ & $\begin{array}{r}168 \\
64 \\
32\end{array}$ & $\begin{array}{r}151 \\
52 \\
23\end{array}$ & $\begin{array}{l}1 \\
0.9 \\
0.8\end{array}$ & $\begin{array}{c}0.6-1.4 \\
0.5-1.5\end{array}$ & $\begin{array}{r}29 \\
9 \\
9\end{array}$ & $\begin{array}{l}1 \\
0.8 \\
1.6\end{array}$ & $\begin{array}{l}0.3-1.8 \\
0.7-3.8\end{array}$ \\
\hline \multicolumn{8}{|c|}{ Climbing $>30$ flights of stairs $/ \mathrm{d}$} \\
\hline $\begin{array}{l}<1 \text { year of exposure } \\
\geq 1 \text { year of exposure }\end{array}$ & $\begin{array}{r}199 \\
61\end{array}$ & $\begin{array}{r}172 \\
53\end{array}$ & $\begin{array}{l}1 \\
1.0\end{array}$ & $0.6-1.5$ & $\begin{array}{l}37 \\
13\end{array}$ & $\begin{array}{l}1 \\
1.2\end{array}$ & $0.6-2.5$ \\
\hline \multicolumn{8}{|c|}{$\begin{array}{l}\text { Lifting or moving weights }>56 \text { lbs } \\
(>25.4 \mathrm{~kg}) \text { by hand }\end{array}$} \\
\hline $\begin{array}{l}<1 \text { year of exposure } \\
1-19 \text { years of exposure } \\
\geq 20 \text { years of exposure }\end{array}$ & $\begin{array}{r}71 \\
106 \\
85\end{array}$ & $\begin{array}{l}62 \\
80 \\
82\end{array}$ & $\begin{array}{l}1 \\
0.9 \\
1.2\end{array}$ & $\begin{array}{l}0.6-1.4 \\
0.7-1.9\end{array}$ & $\begin{array}{r}9 \\
14 \\
26\end{array}$ & $\begin{array}{l}1 \\
1.2 \\
2.5\end{array}$ & $\begin{array}{l}0.5-2.9 \\
1.1-5.7\end{array}$ \\
\hline \multicolumn{8}{|l|}{ Driving for $>4 \mathrm{~h} / \mathrm{d}$} \\
\hline $\begin{array}{l}<1 \text { year of exposure } \\
\geq 1 \text { year of exposure }\end{array}$ & $\begin{array}{r}195 \\
79\end{array}$ & $\begin{array}{r}170 \\
58\end{array}$ & $\begin{array}{l}1 \\
0.8\end{array}$ & $0.5-1.2$ & $\begin{array}{l}33 \\
14\end{array}$ & $\begin{array}{l}1 \\
0.9\end{array}$ & $0.4-1.8$ \\
\hline
\end{tabular}

a Odds ratios were estimated for each activity independently, with adjustment for age and hospital group. 
them to stand for more than $2 \mathrm{~h} / \mathrm{d}$, particularly if they had done this work for at least 40 years (OR 2.7, 95\% CI 1.0-7.3). There was also a significant association with employment for more than 20 years in jobs that entailed heavy lifting (OR 2.5, 95\% CI 1.1-5.7). Weaker associations were found with work that involved walking more than 2 miles $/ \mathrm{d}(3.2 \mathrm{~km} / \mathrm{d})$, particularly if this walking was over rough ground.

The most frequently reported sports activities were soccer, cricket, tennis, and running, but none of these sports was significantly associated with osteoarthritis, whether it was defined to include all cases or only more severe disease. The risk of more severe osteoarthritis increased with body mass index, but again not to the point of statistical significance. The odds ratio for the highest third of the distribution $\left(>27.5 \mathrm{~kg} / \mathrm{m}^{2}\right)$ relative to the lowest third $\left(<24.7 \mathrm{~kg} / \mathrm{m}^{2}\right)$ was 1.6 (95\% CI 0.7-3.4).

The associations with occupational exposure to standing, walking, walking over rough ground, and heavy lifting changed little with allowance for body mass index and participation in soccer, cricket, tennis, and running. They were, however, interrelated. Thus, when the four activities were examined in a single regression model, again with allowance for body mass index and sports, the risk estimates were generally lower than those shown in table 4 . Severe disease was the most strongly associated with more than 20 years of exposure to heavy lifting (OR 2.1, 95\% CI 0.7-6.6) and more than 40 years of exposure to standing (OR 1.6, 95\% CI $0.5-5.1$ ).

\section{Discussion}

In this study our main diagnostic criterion for hip osteoarthritis was joint space narrowing. We have previously shown that minimal joint space is a repeatable measure which correlates with other radiographic features of the disease and with symptoms (18). Its distribution in our sample of urological patients, however, was unimodal, and there was therefore no natural cut-off by which to define the cases. Our choice of $2.5 \mathrm{~mm}$ (the tenth centile in the original sample of radiographs) was arbitrary, and the dearth of associations when the disease was classified in this way suggests that the definition may have been too wide. The tighter cut-off of $1.5 \mathrm{~mm}$ ( $2.7 \%$ of hips) gave a more specific measure of disease, as evidenced by stronger associations with other radiographic changes of osteoarthritis and a higher predictive value for hip pain $(56.0 \%$ compared with $28.3 \%$ ) (18).

By using intravenous urograms as our source of cases and referents, we avoided the bias that is possible when cases are patients who present themselves for diagnosis or treatment of hip symptoms. Some occupational groups may be more inclined to seek medical advice for a given level of disease because it is more of a handicap to them in their work. However, there is no reason why the relative prevalence of osteoarthritis in such occupations should be overrepresented in a sample of urological patients.

Although the number of cases with severe disease was small, our data support earlier studies which have suggested that osteoarthritis of the hip is more common among farmers (12-16). The risk of severe disease for the men with more than 10 years of employment in agriculture was doubled. No other occupation showed a comparable association. Against these positive findings, Lawrence (19) reported no excess of degenerative hip disease among agricultural workers in radiographic surveys of rural populations in England, Germany, and Switzerland, but the numbers of subjects in the relevant age groups were small.

Various mechanisms have been proposed to explain the apparently increased risk of osteoarthritis of the hip among farmers, including stress on the hip joint from heavy lifting and walking over rough ground $(14,20)$. Our data accord with the latter hypothesis in that severe disease was associated with standing, walking and lifting at work, and these associations could not be explained by a confounding effect of obesity or sporting activity. In the only other study to examine the relation of hip osteoarthritis to specific workplace activities, heavy lifting but not prolonged standing was associated with degenerative changes in the joint (14). In studies using broader classifications of occupational activity, associations with heavy physical work have been less consistent $(11,13,21,22)$. We did not ask about work with machinery, but earlier studies have found that tractor driving for long periods carried an elevated risk of hip osteoarthritis $(14,16$, 20). Other possible explanations for the link with farming include a high incidence of infection or childhood hip disorders such as slipped capital epiphysis in agricultural workers. Brucellosis, for example, can cause osteoarthritic change in the hip (23), and slipped epiphysis is more common in rural than in urban areas (24).

The occupational activities which were positively associated with hip osteoarthritis in this study tended to occur together in the same jobs. Given the relatively small number of severe cases, it is therefore not possible to determine which of these activities were of prime importance. Furthermore it is possible that other physical activities that we examined failed to show positive associations because of a lack of statistical power. Larger investigations will be necessary to resolve these questions.

The other determinants of joint stress assessed in this study were leisure activity and body mass index. Most studies of top athletes and sportsmen have found no increase in the occurrence of osteoarthritis of the hip (6-9). These findings agree with our own findings and suggest that sport is unlikely to contribute greatly to the burden of disease in the general population.

A high body mass index is a strong risk factor for knee osteoarthritis (25), but studies of hip osteoarthritis 
have indicated only a weak association with obesity (10) or one confined to certain subgroups of patients $(26,27)$ or no relationship at all $(28,29)$. Our finding of a modest elevation of risk of severe osteoarthritis in the heaviest third of the subjects is consistent with results of a prospective study suggesting that elevated body mass index may influence the progression of established osteoarthritis rather than disease onset (21). As with sport, however, it appears unlikely that obesity can explain much of the burden of degenerative hip disease among the older male population.

The pathogenesis of osteoarthritis at different joint sites broadly depends on the interplay between a generalized susceptibility to the disorder and local mechanical abnormalities. There is ample laboratory evidence supporting a role for mechanical stress in the disease, although whether the stress acts primarily on bone or cartilage is in dispute (30). The relative importance of repetitive use, abnormal use, and overloading is also unclear. This study provides further evidence implicating mechanical overloading in the etiology of osteoarthritis of the hip.

\section{Acknowledgments}

We thank the consultants and staff of the radiology and medical records departments at the North Staffs Central Outpatients Department and the Royal Shrewsbury Infirmary; the general practitioners and family practitioner committees of Staffordshire and Shropshire; and Mr P Winter and Ms C Harris, who helped with the data preparation. The senior author (PC) was in receipt of the Wellcome Training Fellowship in Clinical Epidemiology.

\section{References}

1. Lawrence JS. Rheumatism in cotton operatives. $\mathrm{Br} \mathrm{J}$ Ind Med 1961;18:270-6

2. Anderson JJ, Felson DT. Factors associated with osteoarthritis of the knee in the first National Health and Nutrition Examination Survey (HANES 1): evidence for an association with overweight, race and physical demands of work. Am J Epidemiol 1988;128:179-89.

3. Glyn JH, Sutherland ID, Walker GF, Young AC. Low incidence of osteoarthrosis in hip and knee after anterior poliomyelitis: a late review. Br Med J 1966;2:739—42.

4. Klunder KB, Rud B, Hansen J. Osteoarthritis of the hip and knee joint in retired football players. Acta Orthop Scand 1980;51:925-7.

5. Marti B, Knobloch M, Tschopp A, Jucker A, Howald $\mathrm{H}$. Is excessive running predictive of degenerative hip disease?: controlled study of former elite athletes. $\mathrm{Br}$ Med J 1989;299:91-3.

6. Puranen J, Ala-Ketola L, Peltokallio P, Saarela J. Running and primary osteoarthritis of the hip. Br Med $\mathrm{J}$ $1975 ; 2: 424-5$.

7. Lane NE, Bloch DA, Jones HH, Marshall WH Jr, Wood $\mathrm{PD}$, Fries JF. Long-distance running, bone density, and osteoarthritis. JAMA 1986;255:1147-51.
8. Panush RS, Schmidt C, Caldwell JR, Edwards L, Longley $S$, Yonker $R$, et al. Is running associated with degenerative joint disease? JAMA 1986; 255:1152-4.

9. Sohn RS, Micheli LJ. The effect of running on the pathogenesis of osteoarthritis of the hips and knees. Clin Orthop 1985;198:106-7.

10. Kellgren JH, Lawrence JS. Osteoarthrosis and disk degeneration in an urban population. Ann Rheum Dis 1958;17:388-97.

11. Lindberg $\mathbf{H}$, Danielsson LG. The relation between labour and coxarthrosis. Clin Orthop 1984;191:159-61.

12. Louyot $\mathbf{P}$, Savin R. La coxarthrose chez l'agriculteur. Rev Rhum Mal Osteoartic 1966;33:625-32.

13. Typpo T. Osteoarthritis of the hip: radiologic findings and etiology. Ann Chir Gynaecol 1985;74 Suppl 201: $1-37$.

14. Jacobsson B, Dalen N, Tjornstrand B. Coxarthrosis and labour. Int Orthop 1987;11:311-3.

15. Axmacher B, Lindberg H. Coxarthrosis in farmers as appearing on colon radiograms and urograms. In: Hogstedt C, Reuterwall C, ed. Progress in occupational epidemiology: proceedings of the sixth international symposium on epidemiology in occupational health. Amsterdam: Excerpta Medica, 1988:203-6.

16. Thelin A. Hip joint arthrosis: an occupational disorder among farmers. Am J Ind Med 1990;18:339-43.

17. Office of Population Censuses and Surveys. Classification of occupations. London: Her Majesty's Stationery Office, 1970.

18. Croft P, Cooper C, Wickham C, Coggon D. Defining osteoarthritis of the hip for epidemiologic studies. Am J Epidemiol 1990;132:514-22.

19. Lawrence JS. Rheumatism in populations. London: William Heinemann Medical Books Ltd, 1977.

20. Thelin A. Work and health among farmers: a study of 191 farmers in Kronoberg county, Sweden. Scand J Soc Med Suppl 1980;22:1-126.

21. Van Saase JLCM. Osteoarthrosis in the general population: a follow-up study of osteoarthrosis of the hip [Doctoral dissertation]. Rotterdam: Erasmus University, 1989.

22. Kraus JF, D'Ambrosia RD, Smith EG, Van Meter J, Borhani NO, Franti CE, et al. An epidemiological study of severe osteoarthritis. Orthopedics 1978;1:37-42.

23. Madkour MM. Occupation-related infectious arthritis. Balliores Clin Rheumatol Int Pract Res 1989;3:157-92.

24. Hagglund G, Hansson LI, Ordeberg G. Epidemiology of slipped capital femoral epiphysis in Southern Sweden. Clin Orthop 1984;191:82-94.

25. Felson DT, Anderson JJ, Naimark A, Walker AM, Meenan RF. Obesity and knee osteoarthritis: the Framingham study. Ann Intern Med 1988;109:18-24.

26. Van Saase JLCM, Vandenbroucke JP, Van Romunde LKJ, Valkenburg HA. Osteoarthritis and obesity in the general population: a relationship calling for an explanation. J Rheumatol 1988;15:1152-8.

27. Hartz AJ, Fischer ME, Bril G, Kelber S, Rupley D Jr, Oken $B$, et al. The association of obesity with joint pain and osteoarthritis in the HANES data. J Chronic Dis 1986;39:311-9.

28. Danielsson LG. Incidence and prognosis of coxarthrosis. Acta Orthop Scand Suppl 1964;66:1-114.

29. Saville PD, Dickson J. Age and weight in osteoarthritis of the hip. Arthritis Rheum 1968;11:635-44.

30. Radin EL. The relationship between biological and mechanical factors in the etiology of osteoarthritis. $J$ Rheumatol 1983;10 Suppl 9:20-1.

Received for publication: 5 February 1991 